\title{
Negotiation of meaning in desktop videoconferencing-supported distance language learning
}

\author{
YUPING WANG \\ School of Languages and Linguistics, Griffith University, Brisbane, \\ Queensland 4111, Australia \\ (email:y.wang@griffith.edu.au)
}

\begin{abstract}
The aim of this research is to reveal the dynamics of focus on form in task completion via videoconferencing. This examination draws on current second language learning theories regarding effective language acquisition, research in Computer Mediated Communication (CMC) and empirical data from an evaluation of desktop videoconferencing-supported task completion by distance learners of Chinese. Occasions of focus on form that occurred in this learning environment are explored using the Varonis and Gass model (1985) for negotiation of meaning. Initial findings indicate that videoconferencing-supported negotiation of meaning may facilitate second language acquisition at a distance and has its own distinct features. Issues for future research in the employment of videoconferencing for L2 learning at a distance are suggested.
\end{abstract}

\section{Introduction}

Central to the theory of negotiation of meaning is the argument that interactional modifications make input more comprehensible, thus facilitating L2 acquisition (e.g. Gass 2003; Pica, 1994; Pica, Kanagy, \& Falodum, 1993). Such a facilitating effect has long been established through L2 research and practice in the traditional classroom. However, how can we achieve such interaction in language learning at a distance? With advances in information and communications technology (ICT), new possibilities have been opened up promising immense benefit to distance language learning. As a result, the 21 st century has witnessed a substantial volume of research in Computer Mediated Communication (CMC). Although the majority of these studies relate to the written form of CMC, e.g. the use of email and text chat facilities, the audio and visual forms of CMC have also gained in importance in recent years. Nevertheless, there is still a 
paucity of systematic research on the nature and characteristics of oral and visual interaction supported by videoconferencing-based CMC. This article attempts to bridge the gap in this area by examining how distance language learners interact orally and visually with their teacher, using a videoconferencing tool via their personal computer over the Internet.

This article argues that negotiation of meaning in videoconferencing-supported task completion, in distance mode, can be as conducive to L2 acquisition as that carried out in a traditional face-to-face classroom, though videoconferencing-supported task completion has its own distinctive features. Set against a background of research in L2 acquisition theories and $\mathrm{CMC}$, this hypothesis was further explored in an evaluation involving distance Chinese language learners. Data from nineteen videoconferencing sessions will be presented and discussed. Drawing from these findings, this article raises some issues for future research in regard to the promotion of negotiation of meaning in a videoconferencing-supported distance language context.

\section{Focus on form and the provision of focus on form via CMC}

The area of L2 acquisition sees constant debates on whether, how and when to teach grammar (e.g. Doughty \& Long, 2003; Doughty \& Williams, 1998a; Long, 1991; Long \& Crookes, 1992, 1993; Long \& Robinson, 1998, Pica, Kanagy \& Falodun, 1993). Terms such as focus on form, focus on form $S$ and focus on meaning have become the catch phrases in such debates. As focus on form will be the focal point of analysis in this article, it is necessary to clarify its meaning and boundaries at the outset.

Long has defined and clarified focus on form on several occasions (e.g. Long, 1988; 1991; Long \& Crookes, 1992; Long \& Robinson,1998). The 1998 definition by Long \& Robinson is operational, offering "researchers and practitioners greater direction for practical implementation" (Doughty \& Williams, 1998b: 3):

Focus on form refers to how focal attentional resources are allocated. Although there are degrees of attention, and although attention to forms and attention to meaning are not always mutually exclusive, during an otherwise meaning-focused classroom lesson, focus on form often consists of an occasional shift of attention to linguistic code features - by the teacher and or one or more students - triggered by perceived problems with comprehension or production (op. cit.: 23; emphasis in original).

Three important points arise from the above definition. First and foremost, focus on form happens in a meaning-focused lesson, entailing "a prerequisite engagement in meaning before attention to linguistic features can be expected to be effective" (Doughty \& Williams, 1998b: 3). The second important point is that the attention to linguistic code is not prescribed but triggered by the occasional appearance of problems in the process of negotiation for meaning. As a result, linguistic code features can be learned in a meaningful context, rather than in isolation. Third, the purpose of learners' occasional shift of attention to linguistic forms is to aid comprehension or negotiation of meaning.

Focus on form has been operationalized in L2 learning, especially in task-based learning and has become a guideline for implementing effective task-based instruction 
(e.g. Skehan, 1998). Of the major factors relevant for promoting focus on form identified by Skehan (1998) and Chapelle (2001) are interactional modification, modification of output and support.

Interactional modification is defined by Chapelle (2001: 49) as "interruption of a communication exchange due to a breakdown in comprehension and subsequent attempt to recover from breakdown". Larsen-Freeman and Long (1991: 144) regard it as "a candidate for a necessary (not sufficient) condition for acquisition". Modified output refers to "learners' correction of their own errors - either self-correction or correction prompted by something else" (Chapelle 2001: 49). Support is defined by Chapelle (2001: 49) as "cues or information available to the learner to help in constructing meaning during task completion". These L2 theories are all related to traditional classroom teaching and learning. This research will examine whether they are equally applicable to L2 learning in CMC supported distance mode.

Research on the use of CMC in L2 learning has proliferated in recent years. Wang (2004a) proposed a new taxonomy of CMC-based interaction - written, oral, and oralvisual interaction. As far as written CMC-based interaction is concerned, the literature contains abundant reports on the use of Web-based tools, such as e-mail, Internet Chat Relay, MOO, and Webchat, to improve students' writing skills and reading comprehension (e.g., Chun, 1994; Kern, 1995; Kitade, 2000; Kötter, 2003; Lee, 2004; Negretti, 1999; Pellettieri, 2000; Smith, 2003; Sotillo, 2000; Tudini, 2003, 2005). Investigations into synchronous written interaction mostly generated by Internet Relay Chat also suggest that such interaction may help oral production (e.g., Chun, 1994; Kitade, 2000; Nagretti, 1999).

Reports on the use of audio-conferencing tools are also increasing (see Hampel \& Baber, 2003; Hampel \& Hauck, 2004; Hauck \& Hampel, 2005; Kötter, 2001; Lamy, 2004; Shield et al., 2001).

In comparison to the research in the above two types of CMC-based interaction, research into oral-visual interaction supported by videoconferencing tools seems less voluminous, and relatively, lacking in depth. There are reports on three notable projects using videoconferencing in the 1990s: HIPERNET (McAndrew et al., 1996), LEVERAGE (Wong \& Fauverge, 1999) and ReLaTe (Buckett \& Stringer, 1997; Buckett, Stringer \& Datta, 1999). (For a review of these projects, see Wang (2004a).) These reports mainly concentrate on the technological capabilities and learners' perception of videoconferencing. More recently, Stevens and Altun (2002) report on the Webheads project involving synchronous text-, voice-, and video-enhanced chat. The use of NetMeeting was briefly mentioned by Smith and Salam (2000) when they discussed Web-based ESL courses. Despite the claims (e.g. Andrews, 1993; McAndrew, et al., 1996) that videoconferencing offers great potential for interactive and collaborative task-based learning in distance mode, these claims have not been matched sufficiently by research into the process of such learning and interaction. Consequently, many issues have been left untreated; for example, identifying the quality of negotiation of meaning in videoconferencing-supported task completion, and the factors (i.e. interactional modification, modified output and support) relevant for promoting focus on form which also happen in such a learning environment. This research will investigate these issues by examining instances of interactional modification, modified output and support using the model developed by Varonis and Gass (1985). 


\section{The Varonis and Gass model for negotiation of meaning}

The Varonis and Gass (1985) model treats spoken interaction as a discourse that moves in a horizontal fashion, whereas occasions of non-understanding are regarded as vertical deviations. According to this model, these occasions of non-understanding can be solved through vertical levels of negotiation before the conversation drops back into the horizontal movement. It has to be pointed out that Varonis and Gass's model is limited to the analysis of instances of non-understanding. Non-understanding was operationally defined by Varonis and Gass (1985: 73) as "those exchanges in which there is some overt indication that understanding between participants has not been complete". However, the use of their model in the current research has been extended to include the analysis of all occasions of interactional modification. In Chapelle's (2001) definition, breakdowns are attributed only to incomprehension, whereas when defining occasions of interactional modification, this research encompasses another kind of breakdown, that caused by lack of vocabulary to maintain the horizontal movement of the interaction.

The following two examples illustrate the difference between a breakdown due to a non-understanding and a breakdown due to a request for new words.

An example of non-understanding:

A: Do you have many colleagues who speak Chinese?

$\rightarrow$ B: Colleagues? What does colleague mean?

An example of request for new words

A: Do you have many friends who speak Chinese?

$\rightarrow$ B: No, but I have a ... What is the word for describing people who work with you?

A: Colleagues

The first example shows that Person B does not understand the meaning of the word "colleagues", whereas in the second example, Person B understood the question, i.e. there is no non-understanding. A breakdown still occurs when Person B does not know how to say 'colleagues'.

In the current research, the Varonis and Gass model was used for analysis of interactional modifications caused by both kinds of breakdown. Thus an occasion of interactional modification in videoconferencing-based task completion is characterized by the model contained in Figure 1 which shows that an occasion of interactional modification consists of two parts - a trigger and a resolution, and that there are four functional primes in the model. "Simply put, the trigger [the first prime] is that utterance or portion of an utterance on the part of the speaker which results in some indication of non-understanding on the part of the hearer" (Varonis \& Gass, 1985: 74). The second part of the model, the resolution, consists of the other three primes: an indicator (I), a response $(\mathrm{R})$, and a reaction to the response (RR). An indicator (I) is an "utterance on the part of the hearer that essentially halts the horizontal progression of the conversation" (op. cit.: 75). A response (R) is initiated by the speaker to the indicator, 
acknowledging the non-understanding. The last prime is a reaction to the response (RR). When a resolution is reached, a negotiation routine is considered completed and the conversation resumes its horizontal movement. In order to better understand this model, Table 1 reproduces the model with an example and shows that the first turn initiated by the researcher, in retrospect, serves as a trigger. The second utterance is an explicit request for the meaning of "zuо guai", thus indicating a non-understanding triggered by the previous utterance, and functioning as an indicator. The third turn, "do you know "zuo" is a response to the indicator, and the last turn. "I know, I know" constitutes a reaction to the response.

The significance of this model lies in its identification of the important "players" in the process of interactional modification, thus "allowing us to measure and compare the depth, i.e. the complexity of these non-understandings" (Varonis \& Gass, 1985: 81). Is this equally true when the model is used to analyse instances of focus on form in videoconference supported task completion?

\section{The study}

The empirical dimension of this research saw a two stage evaluation of NetMeetingsupported task completion. NetMeeting 3.01 is an Internet-based desktop videoconferencing tool, enabling point-to-point live transmission of video and audio between people in separate locations. For detailed evaluation of NetMeeting, see Wang (2004 a) and Wang (2004 b).

Stage one of the evaluation involved three on-campus participants, and stage two five students from the Open Learning Chinese program offered at Griffith University. Data discussed here came from the evaluation by the distance participants as distance learning

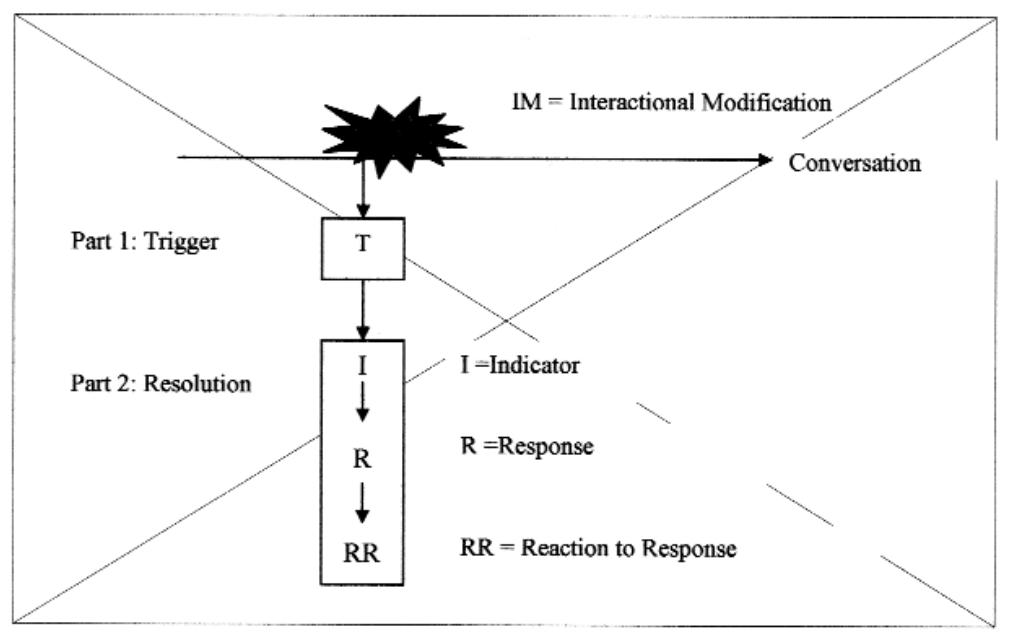

Fig. 1. A model for analysing an occasion of interactional modification during task. Completion. Note: This figure presents a modified version of the Varonis and Gass (1985: 74) model with the negotiation routine shown vertically; this better represents the negotiation process of an occasion of interactional modification. 
Table 1 Discourse model of an occasion of interactional modification with an example. $R=$ researcher, $S=$ Student 2; Session Three, Stage One

\begin{tabular}{|c|c|c|}
\hline $\mathbf{R}$ & Utterance & Function \\
\hline $\begin{array}{c}\text { Gangcai wo xia che de shihou, bu zhidao yinggai wang } \\
\text { zuo guai haishi wang you guai. } \\
\text { When I got off the bus just now, I didn't know whether I } \\
\text { should turn left or right. }\end{array}$ & Trigger \\
\hline $\mathbf{S}$ & $\begin{array}{c}\text { 'Zuo guai' shi shenme yisi? } \\
\text { What does 'zuo guai' mean? }\end{array}$ & Indicator \\
\hline $\mathbf{R}$ & $\begin{array}{c}\text { 'Zuo', zhidao ma? } \\
\text { Do you know 'zuo'? }\end{array}$ & Response \\
\hline $\mathbf{S}$ & $\begin{array}{c}\text { Zhidao, zhidao. } \\
\text { I know, I know. }\end{array}$ & Reaction to Response \\
\hline
\end{tabular}

is the focus of this research. They were designated as Participants A, B, C, D and E.

Five one-to-one videoconferencing sessions were scheduled between the teacher and each participant with the aim of completing various speaking tasks (for task descriptions, see appendix 1) in Chinese, the target language, and nineteen successful sessions of one to one-and-a-half-hours' duration were obtained. All these sessions were conducted through NetMeeting while the teacher and the participants were at different locations in Australia. The sessions were videotaped, and occasions of focus on form were transcribed and analyzed using the Varonis and Gass model (1985). A qualitative approach has been adopted to capture the features of the participants' experience as the objective of the evaluation was to investigate the process of focus on form.

This research recognizes the small sample size, although in a qualitative investigation the number of participants is not crucial. In view of this limitation, established L2 acquisition theories and empirical studies in CMC research are drawn on in discussing results and implications, in order to avoid over generalization from the small sample size.

\section{Data analysis}

The analysis of individual instances of interactional modification covers the two parts of the negotiation routing (the trigger and the resolution), and the various types of the four primes as discussed in the work by Varonis and Gass (see Figure 1). Due to space limitations, examples of different categories of the four primes are selected on the basis of their high frequency of appearance in the data. Some of the examples are reproduced in order to demonstrate that in one instance of interactional modification, all four types of primes existed. Emphasis is given to examples not covered in the study of Varonis and Gass, such as Examples 4, 7, 8 and 14. 


\section{A. Triggers}

According to Varonis and Gass (1985: 75), triggers can come from a question, an answer to a question or neither a question nor an answer. Data from the current research provide examples of all three kinds of triggers.

Trigger as question

This type of trigger occurred mostly with participants with low listening ability, as shown in Example 1. Triggers are indicated by an arrow.

\section{Example 1}

( $\mathrm{R}=$ researcher, $\mathrm{P}=$ Participant $\mathrm{D}$, Session Five $)$

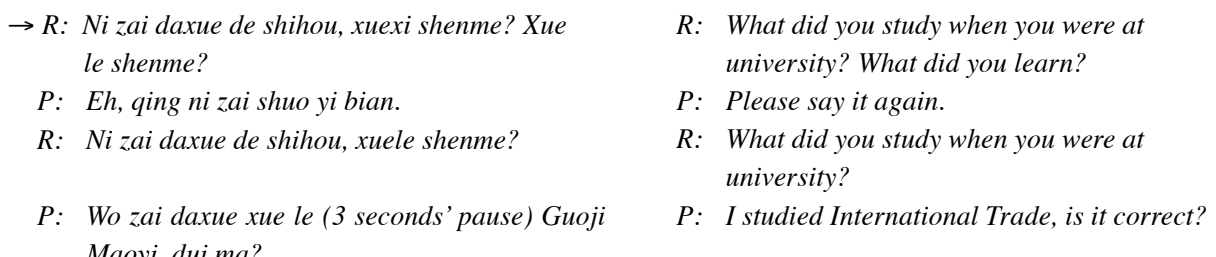

In Example 1, the trigger question is a simple sentence containing no unknown words or structure as far as the participant was concerned. After the researcher repeated the question, comprehension occurred. This process also happened with other participants. In the post session interviews, participants clarified that in most instances, it was their poor listening that triggered the breakdown, rather than the sound quality of the videoconferencing. For example, Participant A explained:

It's very hard for me to hear. I have the difficulty of understanding spoken Chinese. I can, if you write the words, I can try to understand, but I find it very hard to listen.

\section{Trigger as answer}

In Example 2, the researcher could not make out Participant C's pronunciation of jiawushi. It was not until the participant explained jiawushi (house work) in English that the researcher realized that the non-understanding was triggered by the participant's incorrect pronunciation of jiawushi (see Example 2).

\section{Example 2}

( $\mathrm{R}=$ researcher, $\mathrm{P}=$ Participant $\mathrm{C}$, Session Three)

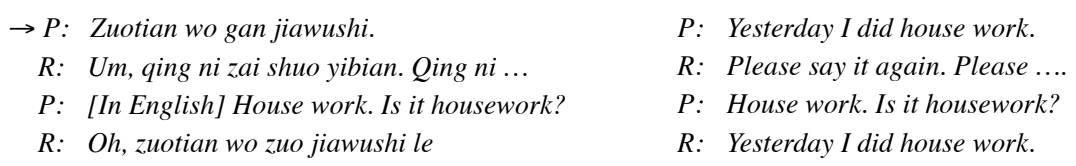

Trigger as neither question nor answer

In Example 3, the trigger comes from neither a question nor an answer, when Participant $\mathrm{C}$ was trying to describe her family members. 


\section{Example 3}

$(\mathrm{R}=$ researcher, $\mathrm{P}=$ Participant $\mathrm{C}$, Session Two)

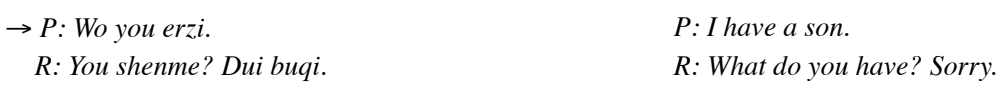

The non-understanding in Example 3 was again caused by the participant's incorrect pronunciation of erzi. A new type of trigger that was not discussed in the Varonis and Gass study occurred in this research: triggers caused by unknown words or phrases. Example 4 illustrates this category of trigger.

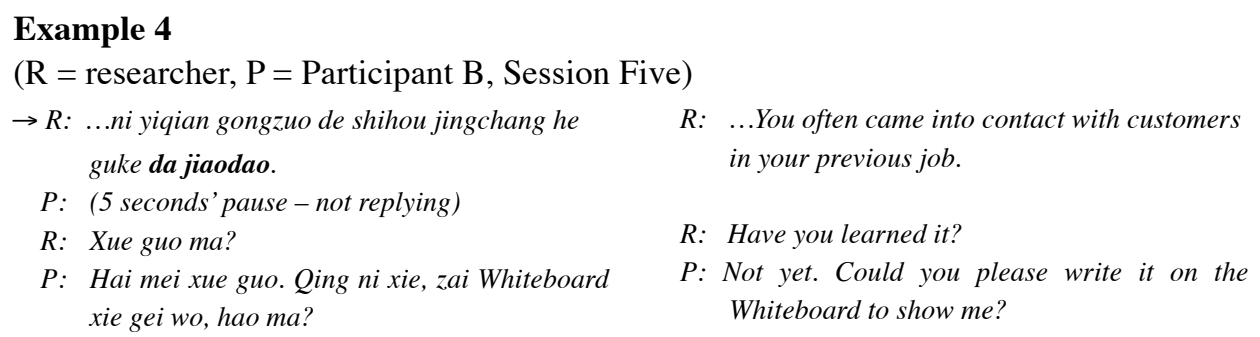

The trigger, da jiaodao, was deliberately embedded by the researcher to raise Participant B's awareness of this phrase, anticipating that the participant would negotiate the meaning of the phrase. Seeing no immediate reaction from the participant, the researcher checked the participant's understanding by asking if he had learned the phrase before. Participant B confirmed that he had not and requested the researcher to write it on the Whiteboard. The researcher only employed this kind of trigger occasionally with participants at a higher level of Chinese proficiency for the purpose of creating occasions for beneficial focus on form during task completion.

\section{B. Indicators}

Indicators signal the start of a breakdown in interaction. Varonis and Gass (1985: 76) identified four types of indicator: echo, explicit statement of non-understanding, nonverbal response and inappropriate response. In data collected in this evaluation, all four types of indicator existed. Furthermore, visual indicators of non-understanding constitute another type of indicator which was not covered in Varonis and Gass's study. Examples of the two most frequent types of indicators are discussed below.

\section{Explicit statements of non-understanding}

There were two types of such statements if categorized according to their sources: breakdowns due to participants' low listening skills and breakdowns due to unknown linguistic elements. Data in regard to the former type of breakdown correspond with triggers as questions (see Example 1). At the start of the trial, such nonunderstanding was usually expressed in English as shown in Example 5. After the researcher emailed the participants a list of frequently used phrases, the participants started to indicate their non-understanding in Chinese as with Example 6.

\section{Example 5}

$(\mathrm{R}=$ researcher, $\mathrm{P}=$ Participant $\mathrm{A}$, Session One 
R: Oh, OK. Ni jintian zuo shenme le?

$\rightarrow R:$ What have you done today?

$P: \quad(($ Looking puzzled and trying hard to understand)) (3 seconds' pause) I don't understand.

\section{Example 6}

$(\mathrm{R}=$ researcher, $\mathrm{P}=$ Participant $\mathrm{D}$, Session Five $)$

R: Ni zai daxue de shihou, xuexi shenme? Xue le

R: What did you study when you were at shenme?

$\rightarrow P$ : Eh, qing ni zai shuo yi bian.

P: Please say it again.

The second type of breakdown often emerged when participants found they did not have the vocabulary to finish their turns, as demonstrated in example 7.

\section{Example 7}

( $\mathrm{R}=$ researcher, $\mathrm{P}=$ Participant $\mathrm{B}$, Session Four)

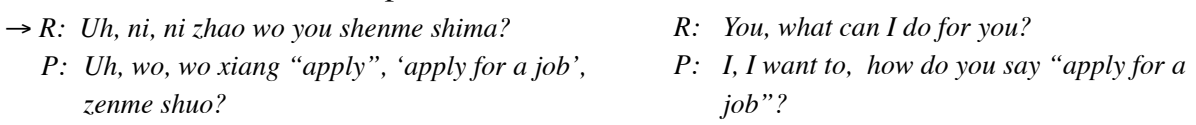

The participant's turn broke down because he did not know how to say 'apply' in Chinese. This type of breakdown is a by-product of meaning-based tasks, which require the learner to convey meaning using resources, sometimes beyond what they have learned, thus creating opportunities for focus on form. The study by Varonis and Gass did not incorporate such breakdowns.

\section{Visual indicators}

Through the function of video in NetMeeting, another type of indicator occurred: nonunderstanding visualized through facial expressions. Often a puzzled or blank look indicated that incomprehension was experienced. This is similar to but more natural than the graphic representations used in CMC-based written interaction. Again this type of indicator was not present in Varonis and Gass's study (see Example 8).

\section{Example 8}

( $\mathrm{R}=$ researcher, $\mathrm{P}=$ Participant $\mathrm{A}$, Session One)

\footnotetext{
$R$ : Ni jintian zenme yang?

R: How are you today?

$\rightarrow P$ : Um, (looking puzzled again, not answering, 5 seconds' pause).

$R:$ Ni jintian mang bu mang? R: Are you busy today?
}

$\rightarrow P$ : (looking puzzled and trying to work out the meaning, 15 seconds' pause). I'm a bit nervous.

Can you say it again? [...]

The above example also demonstrates the importance of visual cues in negotiation of meaning, and the capability of videoconferencing tools in the provision of such visual information to aid understanding.

\section{Responses}

Response is a turn that reacts to the cause(s) of the breakdowns expressed in the indicator. According to Varonis and Gass (1985: 76), there are different types of response: repetition, expansion, rephrasing, acknowledgement and reduction. All of 
these types were found in the current study, with an additional type, direct Chinese equivalent of the unknown phrases or words requested in the indicators.

\section{Repetition}

This type of response materialized more often in the first few sessions. Usually, the participants explicitly requested the repetition, as shown in Example 9.

\section{Example 9}

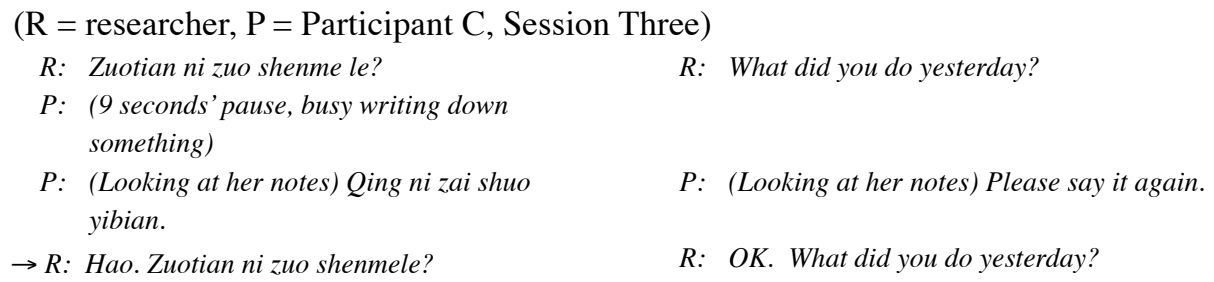

After the repetition, comprehension could usually be achieved. It was also discovered that as the sessions went on, repetitions became less frequent.

\section{Expansion}

In order to explain certain words or sentences, expansion sometimes occurred in the researcher's turns. In Example 10, the researcher tried to explain the sentence, Ni jia hai you shenme ren (who else is there in your family), in the context of mentioning other members of the family.

\section{Example 10}

( $\mathrm{R}=$ researcher, $\mathrm{P}=$ Participant $\mathrm{C}$, Session Two)
$R$ : Ni jia hai you shenme ren?
$R$ : Who else is there in your family?
P: (looking at her notes) Qing ni zai shuo yibian.
$P$ : (looking at her notes) Please say it again.
$\rightarrow R$ : Hao. Ni jia hai you shenme ren? Ni you yi
$R$ : $O K$. Who else is there in your family? You have ge erzi, liang ge nu'er, hai you shenme ren? one son and two daughters, who else?

\section{Rephrasing}

Rephrasing is another type of response used by the researcher to get the meaning across. Usually the words in the rephrased sentence were those that the researcher was certain that the participants had learned (see Example 11).

\section{Example 11}

( $\mathrm{R}=$ researcher, $\mathrm{P}=$ Participant $\mathrm{A}$, Session One $)$
$R$ : Ni jintian zenme yang?
R: How are you today?
$P: \quad$ Um, (looking puzzled again, not Answering, 5 seconds' pause)
$\rightarrow R$ : Ni jintian mang bu mang?
R: Are you busy today?

In Example 11, when realizing that zenme yang (how) might be causing the nonunderstanding, the researcher replaced it with mang bu mang (busy or not busy).

Acknowledgement

Acknowledgement that what the participants said was correct often occurred when a 
comprehension check was received. Such comprehension checks could appear in words, or visually through the function of the video in NetMeeting.

\section{Example 12}

$(\mathrm{R}=$ researcher, $\mathrm{P}=$ Participant $\mathrm{D}$, Session Five $)$
P: Wo zai daxue xue le (3 seconds' pause) Guoji $\quad P:$ I studied (3 seconds'pause) International Trade, Maoyi, dui ma? (Looking at the researcher is it correct? (Looking at the researcher for for confirmation of his use of International confirmation of his use of International Trade, Trade, a phrase he had just learned) a phrase he had just learned)
$\rightarrow$ R: Dui, dui.
R: Correct, correct.

\section{Reduction}

Reduction of the trigger sentence often occurred when the researcher realized that a certain part of the sentence was causing the communication breakdown (see Example 13).

\section{Example 13}

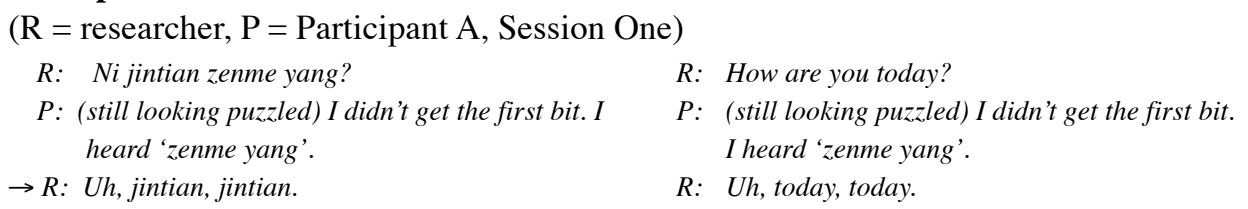

In Example 13, the researcher realized that the participant had not understood jintian (today), so reduced the whole utterance to jintian and repeated it. As the teacher of the distance Chinese program, the researcher was certain that the participant had learned jintian, but had probably forgotten it.

\section{Target language equivalent}

As a response to participants' requests for unknown Chinese words, an equivalent in Chinese was provided by the researcher immediately following the indicator (see Example 14).

This is probably because this type of response often came from the researcher, who is a native speaker of the target language. Varonis and Gass do not cover this category of response in their study.

\section{Example 14}

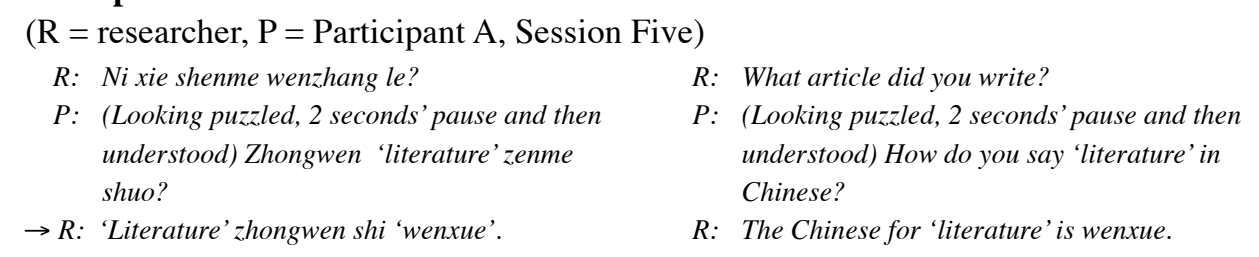

\section{Reaction to response}

Reaction to response was treated as an optional element by Varonis and Gass (1985: 77). However, it was found in the current study that reaction to response is an important prime, often indicating that some degree of acquisition had occurred as the result of a 
breakdown. Comprehension and modification of output are the two major types of reaction to response. Comprehension of what had been said in the trigger sentences occurred often following the repetition in responses.

\section{Example 15}

( $\mathrm{R}=$ researcher, $\mathrm{P}=$ Participant $\mathrm{D}$, Session Five)

R: Ni zai daxue de shihou, xuexi shenme? Xue le shenme?

P: Eh, qing ni zai shuo yi bian.

$R$ : Ni zai daxue de shihou, xuele shenme?

$\rightarrow P$ : Wo zai daxue xue le (3 seconds'pause) Guoji Maoyi, dui ma? (Looking at the researcher for confirmation of his use of International Trade, a phrase he had just learned)

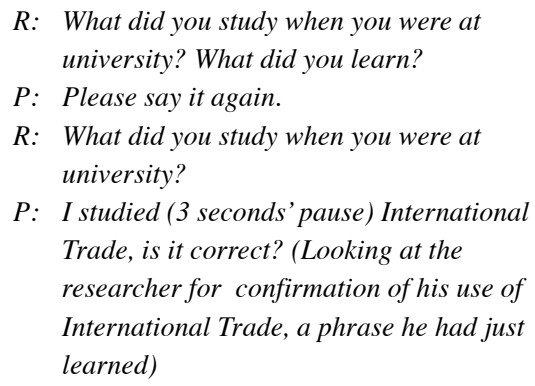

R: What did you study when you were at university?

P: I studied (3 seconds' pause) International Trade, is it correct? (Looking at the researcher for confirmation of his use of International Trade, a phrase he had just learned)

$R$ : correct, correct.

\section{Example 16}

( $\mathrm{R}=$ researcher, $\mathrm{P}=$ Participant $\mathrm{A}$, Session Two)

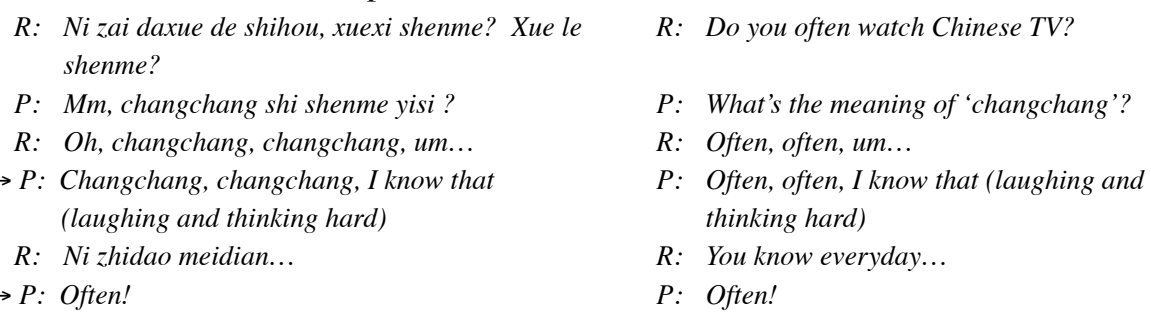

In Example 15, after the researcher repeated the same question, asking him what he learned at the university, Participant $\mathrm{D}$ understood the questions and proceeded to answer that he learned International Trade. However, Example 16 illustrates a different kind of understanding. At first, Participant A could not understand changchang (often) but she was sure that she had learned it before. After the repetition in the researcher's turn, Participant A finally recalled that it meant 'often'.

Examples 17 and 18 best illustrate how reaction to response facilitated modified output in the exchanges.

\section{Example 17}

( $\mathrm{R}=$ researcher, $\mathrm{P}=$ Participant $\mathrm{C}$, Session Three)
R: Hao. Zuotian ni zuo shenme le?
$R:$ OK. What did you do yesterday?
$P$ : (3 seconds'pause) Zuotian wo shangban.
$P$ : (3 seconds' pause) Yesterday I go to work.
$R$ : Hao. Zuotian wo shangban le.
R: $O K$. I went to work yesterday.
$\rightarrow P$ : Shangban le.
$P$ : went to work.

\section{Example 18}

$(\mathrm{R}=$ researcher, $\mathrm{P}=$ Participant $\mathrm{E}$, Session One $)$ 

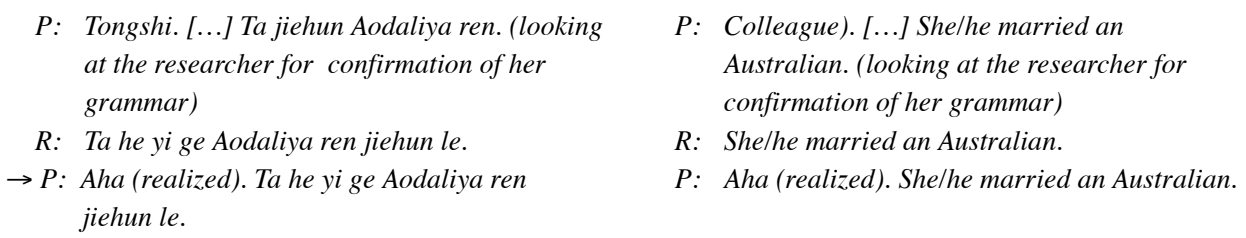

Participant C's interactional and listening skills were almost non-existent when the trial first started, and she appeared to be very nervous in the first two sessions. Although listening was still a problem for her in Session Three, Example 17 shows that she could detect her grammatical error and quickly modify her output by using $l e$ after hearing the researcher's stress on $l e$. In the latter part of the session, Participant $\mathrm{C}$ became conscious of the use of le and used it later in "wo zuo le rou" (I cooked meat) and "wo hai zuo le qingcai" (I also cooked some vegetables). The same learning process happened to Participant E in Example 18, who corrected her sentence structure immediately after hearing the correction in the researcher's response.

\section{Support}

Support refers to cues or information available to aid negotiation of meaning during task completion. Data from this research indicates that the NetMeeting-supported distance learning environment offered many types of support, which proved to be crucial for successful negotiation of meaning. Examples of five major types of support are presented and discussed below: the function of the video, the Whiteboard, Document Sharing, File Transfer and My Video.

\section{The video}

The most valuable support was found in the video. Body movements above the shoulders were all present during the videoconferencing sessions. Facial expressions such as an expectant look or raised eyebrows conveyed the intended message accurately during focus on form, as shown in Example 19.

\section{Example 19}

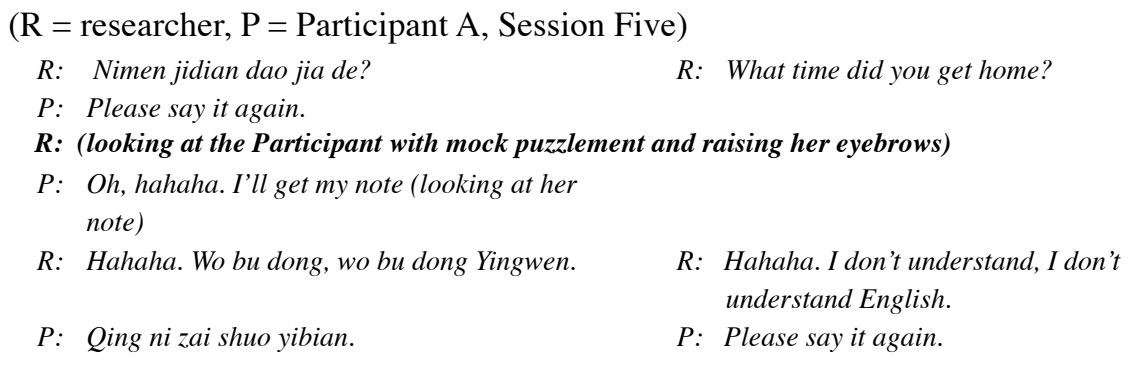

In Example 19, Participant A asked the researcher to repeat what she had said, but she rendered her request in English. To encourage her to speak Chinese, the researcher pretended that she did not understand the request by putting on an expression of incomprehension and raising her eye brows in anticipation. Through the real-time video transmission, the participant immediately understood the researcher's intention and 
laughed, saying she would consult her notes and see how to make the request in Chinese. The last turn in the example demonstrates that she eventually made her request using Chinese. Instances of the video in transmitting facial expressions in real time during negotiation of meaning were abundant in the data collected, as shown in some of the examples above.

The function of the video was also used to demonstrate hand gestures to aid negotiation of meaning, usually deliberately by the researcher. For example, when talking about numbers, the researcher would put up three fingers in front of the Web camera to indicate the number three. However, in Session Four, it was Participant B who requested the researcher to write characters using finger movements in front of the Web camera. To show his understanding of how the characters were written, the participant also wrote with his index finger in front of the camera following the researcher's finger movements.

The video was also employed to show objects in promoting the authenticity of the tasks. For example, in Session Four, Participant A showed pictures of her family and her dogs through the video when completing the task on talking about family members.

The importance of video was generally viewed in terms of its support to communicative language acquisition. For example, in the interview at the completion of Session 2, when asked how often he looked at the video, Participant B replied:

I, I looked at the image all the time. I think it's quite import, quite important, you know, form. You want to see the, the a, reaction, the facial expressions, because that's part of the communication.

\section{The Whiteboard}

Apart from the video, the Whiteboard was the second most frequently used function offered through NetMeeting.This on-screen feature functions similarly to the Whiteboard in traditional classrooms in that the teacher can use it to illustrate a point. However, they differ in many ways. The Whiteboard in NetMeeting allows both parties to view, edit or draw simultaneously. In addition, information from any Windows-based application can be cut, copied and pasted onto the Whiteboard. In this research, the Whiteboard was utilized in almost every session for character writing and picture drawing to aid focus on form. Figure 2 is an example of the use of the Whiteboard during NetMeeting sessions.

The pictographic nature of the Chinese characters may contribute to the frequent use of the Whiteboard function as it is easier to figure out the meaning when seeing the characters on the Whiteboard, rather than only hearing them. This is perfectly exemplified by the following instance of interactional modification:

\section{Example 20}

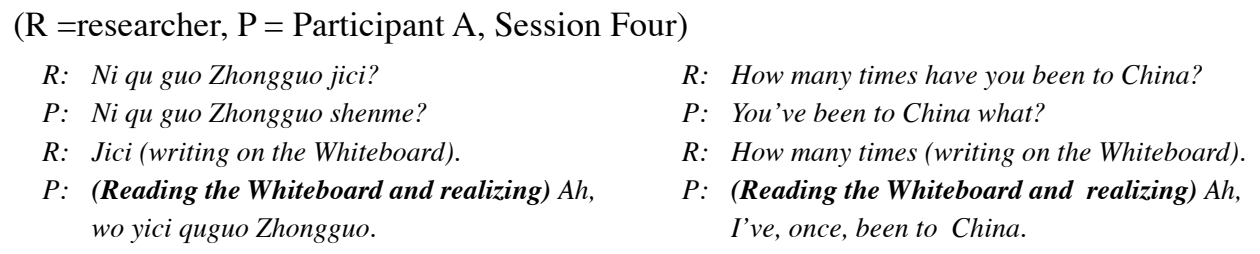




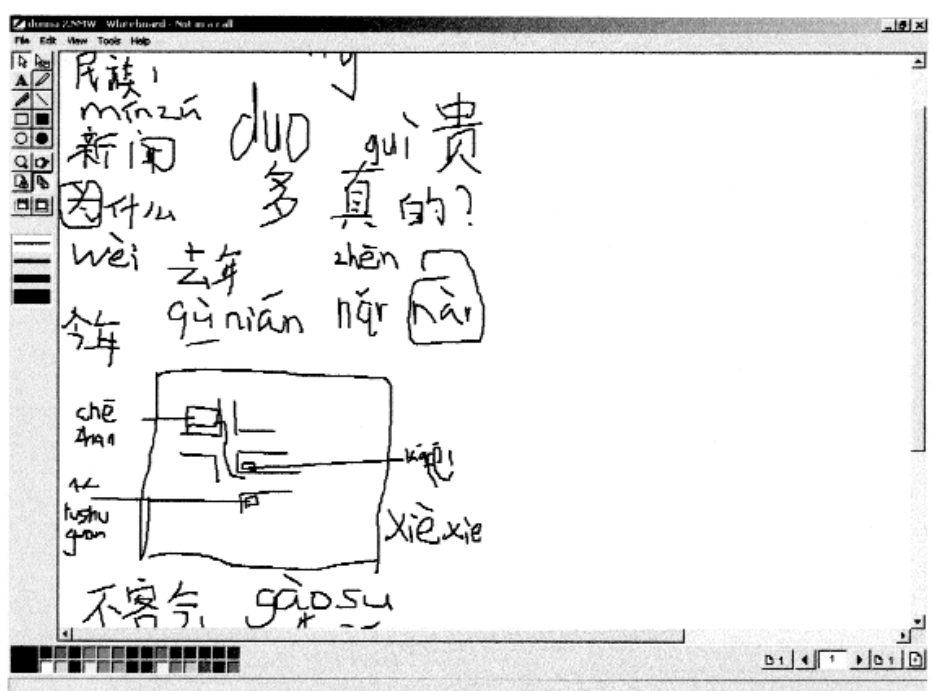

Fig. 2. The whiteboard contents of session three with Participant A.

Example 20 shows that Participant A did not understand jici (how many times) until she saw it written on the Whiteboard. She had obviously learnt this phrase because she showed her understanding of it by saying yici (once) in her reply, although she put it in the wrong place.

\section{Document Sharing}

This function was another type of support available through NetMeeting. During task performance, this function was employed in order to share with the participants documents such as a menu in a café and some lecture notes prepared beforehand. It was discovered that this function complemented the Whiteboard in that, through Document Sharing, more organized information in a larger volume could be made available to the students immediately, while the Whiteboard could be used for spontaneous explanations of linguistic codes. For example, when explaining how to ask about one's age in Session Four with Participant A, the lecture note outlining the three ways of asking one's age was shown to the participant through the function of Document Sharing. As an alternative to pre-saved Whiteboards, it saved online time because it was not necessary to write the questions one by one on the Whiteboard.

\section{Document Transfer}

This function also supported authentic task performance in that it transferred authentic documents to the other party for either in class or out of class reviewing. For example, when conducting the task on talking about family members, a .jpg file was transferred to the participants through this function, and lively discussions in Chinese were generated in relation to this photo.

My Video

My video is a picture-in-picture self-image window on the computer screen where one 
can see oneself while watching the video image of the other party. The researcher utilized this function constantly in every session to ensure that her paralinguistic cues promoted negotiation of meaning, as shown in Example 19. Participant A used it to adjust the photos she wanted to show the researcher through the Web camera.

\section{Discussion}

In reference to $\mathrm{L} 2$ acquisition theories and CMC research, data presented above will be further examined here, with particular emphasis on features offered through videoconferencing and examples not covered in the Varonis and Gass study.

Data indicate that the largest trigger type is trigger as question (see Example 1). The following factors might have contributed to the causes of this type of trigger. Firstly, the participants' low level of listening skills played a major part in the breakdowns, as confirmed in the post session interviews and the researcher's observation. Secondly, the effects of the online learning environment should also be taken into consideration; for example, the sound and video quality (see Wang, 2004b), and the participants' familiarity with the features of NetMeeting. Thirdly, breakdowns could also have been triggered by participants' nervousness about the online learning environment or even the combination of all these factors. Without comparison to face-to-face interaction, in some instances, it was difficult to assess whether or to what extent these factors had contributed to the breakdowns in understanding between participants and the researcher.

Triggers caused by unknown words are not covered in the model developed by Varonis and Gass but deserve some attention here. With more advanced participants, the researcher deliberately created triggers for beneficial focus on form (see Example 4). However, with less advanced participants, the researcher placed more weight on helping them to complete the tasks by avoiding using new vocabulary and sentence structures. Such control at the task performance level indicates that the frequency of occasions of focus on form, to some extent, can be determined by the participants. Here a crucial issue arises that deserves investigation beyond this article, i.e., how to maintain an appropriate balance between focus on form and focus on meaning in task completion supported by videoconferencing.

Analysis of the indicators of breakdown in conversation further reveals participants' low listening and speaking skills. The average participants seemed to possess few interactional skills and phrases in Chinese, such as clarifying meaning and checking understanding in Chinese, especially in the first few videoconferencing sessions.

Lack of vocabulary constitutes another type of indicator of breakdown. Interestingly, this type of indicator occurred more with participants of higher Chinese proficiency than with those of lower proficiency. This was, to a certain extent, determined by the openended nature of meaning-focused tasks, as learners are not restricted to the use of any vocabulary or sentence structures.

Typical of the videoconferencing supported environment were the visual indicators emerging from the sessions. This type of indicator was not found in the Varonis and Gass (1985) study. Similar to visual cues in face-to-face interaction, facial expressions such as a puzzled look, an expression of confusion, and signs of comprehension and enjoyment, were often received accurately by the other party in the conferencing. Cognitively and linguistically, it has been generally maintained that paralinguistic cues 
reduce misunderstanding and ambiguity in speech. (See Bruce, 1996, for a review.) Data from this research indicate that, even with varying degrees of delay, these visual cues transmitted through NetMeeting promoted understanding and communication. In fact, the visual information became even more crucial when the sound quality of a videoconferencing session was sometimes imperfect. Parties at both ends of the videoconferencing often relied on the video transmission to confirm understanding or non-understanding as shown in examples 12, 14 and 19.

Data show that a variety and abundance of responses emerged during the videoconferencing sessions, including all the types discussed in the Varonis and Gass (1985) study, and with the additional type: target language equivalent. What is worthy of deliberation here are the reasons for the variety of responses. Here the advantage of the one-to-one nature of NetMeeting clearly manifested itself. The one-to-one interaction allowed the researcher to provide immediate and specific responses to the indicators from the participants, thus catering for the differences in and special needs of individual learners. It was discovered that this one-to-one mode especially suited the participants because of their limited listening and speaking skills and their varied Chinese proficiency levels.

In the Varonis and Gass (1985) study, reaction to response was treated sparsely, and was only regarded as an optional prime in the negotiation routine, which ties up the negotiation routine before the horizontal movement of the conversation resumes. They did not elaborate on the implications of reaction to response for language acquisition. However, data from this research indicate that reaction to response is a valuable prime when we determine the level of L2 acquisition resulted from an occasion of interactional modification. This is because reaction to response in this research witnessed a large number of modified outputs, indicating successful focus on form. These modifications of output often occurred following the specific responses from the researcher, which facilitated understanding and learning of new linguistic code features. Reaction to response happened in every instance of focus on form, again, thanks to the one-to-one nature of NetMeeting. In such interaction, unlike multi-way interaction, the researcher's responses were directed more immediately and accurately to the specific needs of individual participants, who were "forced", to some extent, to react to the response. Thus the exchanges between the two parties were much more intensive than in a multi-way interaction. Furthermore, in view of the diverse proficiency levels of the distance participants, a multi-way discussion in the target language would waste a great deal of valuable online time. In fact, Hampel and Hauck (2004: 75) report that one of the improvements in audio conferencing activities suggested by their participants is that "more pair work and less whole group work could be done to increase the actual time people are speaking in the target language". O'Dowd (2000: 57) also reports that participants in a larger group were less positive about the potential of videoconferencing in foreign language learning than those in a smaller group, because it was "difficult for all students to speak with their partners as much as they might have wished". Thus, in a one-to-one interaction, reaction to response could be an important indicator of L2 acquisition, and should attract more attention in future research.

Data further demonstrate that NetMeeting was able to offer valuable support to negotiation of meaning. For more discussion on these features, also see Wang (2004a; 2004b). Despite some technical limitations, a multi-modal learning environment was 
offered to the learners with the support of the video, the Whiteboard, File Transfer, Document Sharing and My Video. The multimodal nature of videoconferencing-based interaction has been regarded as beneficial to negotiation of meaning in L2 acquisition (see Chun \& Plass, 2000), and was greatly appreciated by the participants in this research. The combination of these features also helps to create an effective language learning environment, conducive to task completion. Thus the capability of videoconferencing for assisting the completion of mean-based tasks was confirmed. The issue of choosing the appropriate technology to realize the focus of the task has gained increasing attention from CMC research (see Levy, 2004).

\section{Implications}

Data from this research direct us to many issues that should be further explored in the future. First, what is the appropriate density of occasions of focus on form for an online speaking task? Long and Robinson (1998: 23) suggest "an occasional shift of attention to linguistic code features". Then how should we maintain this "occasional shift" when learners' proficiency levels vary?

Second, how can the best advantages be taken of videoconferencing features such as the video, audio, the Whiteboard, File Transfer and Document Sharing? Data from this research confirm the pedagogical soundness of these features, which could be further explored in future research.

Third, this research also draws our attention to the issue of teacher training. As videoconferencing facilitates a new context for oral-visual interaction, effectively managing this multimodal learning environment will pose new challenges to distance language professionals. Different from a face-to-face lecture, the one-to-one nature of desktop videoconferencing calls for sustained concentration, careful planning and awareness of and sensitivity to individual learners' needs.

Last but not least, the psychological readiness of distance language professionals is becoming an increasingly urgent issue. Interaction in a videoconferencing environment is similar to that of face-to-face but differs from it in important ways. For example, the combination of video, audio, text and other links enriches the learning environment, but at the same time can place considerable pressure and strain on the teacher as well as the learner. In such a multimodal environment, coping with the intensive demands of the technology and the learner is a new challenge to teachers. Furthermore, due to a variety of reasons, especially the instability of Internet services, videoconferencing sessions can fail. Distance language professionals have to be prepared for failures of this kind and encourage themselves and the learner to persevere. The psychology of interaction in the videoconferencing environment deserves more attention and research from language professionals as this new teaching and learning medium becomes more widely used.

\section{Conclusion}

This article explores the occasions of interactional modification that occurred during 19 real-time sessions conducted through NetMeeting. Examples of interactional modification have been analyzed using Varonis and Gass's model (1985). This model has proved to be a useful tool to reveal the instances of focus on form in negotiation of 
meaning, and to characterize the complexity and depth of those instances. Employing this model, this research has identified the various causes of these breakdowns and indicators of L2 acquisition (e.g. modified output) by unfolding the process of interactional modification. Most importantly, the Varonis and Gass model assists this research in reaching the conclusion that beneficial focus on form also occurs in videoconferencing-supported task completion. In other words, videoconferencing allowed the participants to modify their interaction when there was a breakdown in task completion, thus facilitating L2 acquisition. This model also demonstrates that videoconferencing-supported negotiation of meaning has its own distinct features in comparison to face-to-face interaction. In employing this model in the analysis of the videoconferencing-supported interaction in distance language learning, this research has also enriched and improved the model to make it more comprehensive.

To my knowledge, there has been no other empirical investigation in the literature which evaluates the negotiation of meaning in a NetMeeting-supported distance language learning environment. This study therefore fills a gap by addressing significant issues in videoconferencing-supported distance language learning. It also suggests a possible model for integrating desktop videoconferencing into distance language learning, one which serves not as an extension or add-on component of an existing program, but as a vital solution to what has been practically lacking.

\section{Acknowledgements}

The author would like to thank Associate Professor Mike Levy and Professor Nick Knight for their valuable suggestions and comments on an earlier draft of this article. Thanks also go to the referees of this article, whose comments have reshaped it in many ways.

\section{References}

Andrews, T. (1993) Videoconferencing: an interactive communication tool for distance learners. ONCALL, 8(1), http://www.cltr.uq.edu.au/oncall/andrews81.html

Buckett, J. and Stringer, G. (1997) ReLaTe: A case study in language teaching using the MBone. http://www.ex.ac.uk/pallas/relate/papers/ukerna97.html [2001, 28 November].

Buckett, J., Stringer, G., and Datta, N. K. J. (1999) Life after ReLaTe: Internet videoconferencing's growing pains. In: Cameron, K. (ed.), CALL and the learning community. Exeter: Elm Bank Publications, 3-38.

Chapelle, C. A. (2001) Computer applications in second language acquisition: Foundations for teaching, testing and research. Cambridge: Cambridge University Press.

Chun, D. (1994) Using computer networks to facilitate the acquisition of interactive competence. System, 22(1): 17-31.

Chun, D. M. and Plass, J. L. (2000) Networked multimedia environments for second language acquisition. In Warschauer, M. and Kern, R. (eds.), Network-based language teaching: Concepts and practice. Cambridge: Cambridge University Press, 151-170.

Doughty, C. and Long, M. H. (2003) Optimal psycholinguistic environments for distance foreign language learning. Language Learning \& Technology, 7(3): 50-80.

Doughty, C. and Williams, J. (1998a) Focus on form in classroom second language acquisition. Cambridge: Cambridge University Press. 
Doughty, C. and Williams, J. (1998b) Issues and terminology. In: Doughty, C. and Williams, J. (eds.), Focus on form in classroom second language acquisition. Cambridge: Cambridge University Press, 1-11.

Gass, S. M. (2003) Input and interaction. In: Doughty, C. J. and Long, M. H. (eds.), The handbook of second language acquisition. Malden, MA: Blackwell Publishing Ltd, 224-255.

Hampel, R., and Baber, E. (2003) Using Internet-based audio-graphic and video conferencing for langauge learning. In: Felix, U. (ed.), Language learning on-line: Towards best practice. Lisse, The Netherlands: Swets \& Zeitlinger,171-191.

Hampel, R. and Hauck, M. (2004) Towards an effective use of audio conferencing in distance language courses. Language Learning \& Technology, 8(1): 66-82.

Hauck, M., Hampel, R. and Tudini, V. (2005) The challenges of implementing online tuition in distance language course: Task design and tutor role. In: Holmberg, B., Shelley, M. and White, C. (eds.), Distance Education and Languages: Evolution and Change. Clevedon: Multilingual Matters Ltd, 212-229.

Kern, R. (1996) Computer-mediated communication: Using e-mail exchanges to explore personal histories in two cultures. In: Warschauer, M. (ed.), Telecollaboration in foreign language learning. Honolulu, HI: University of Hawaii, Second Language Teaching \& Curriculum Centre, 105-119.

Kitade, K. (2000) L2 learners' discourse and SLA theories in CMC: Collaborative interaction in Internet chat. Computer Assisted Language Learning, 13(2): 143-166.

Kotter, M. (2001) Developing distance language learners' interactive competence - Can synchronous audio do the trick? International Journal of Educational Telecommunications, 7(4): 327-353.

Kotter, M. (2003) Negotiation of meaning and codeswitching in online tandems. Language Learning and Technology, 7(2): 145-172.

Lamy, M. (2004) Oral conversations online: Redefining oral competence in synchronous environments. ReCALL, 16(2): 520-538.

Larsen-Freeman, D. and Long, M. H. (1991) An introduction to second language acquisition research. London: Longman.

Lee, L. (2004) Learner's perspectives on networked collaborative interaction with native speakers of Spanish in the US. Language Learning \& Technology, 8(1): 83-100.

Levy, M. (2005) Effective of CALL technologies: Finding the right balance. In: Donaldson, R., and Haggstrom, M. (eds.), Changing Language Education Through CALL. London: Taylor \& Francis, 1-17.

Long, M. H. (1988) Focus on form: A design feature in language teaching methodology. European-North-American Symposium on Needed Research in Foreign Language Education, Bellagio, Italy: Rockefeller Centre.

Long, M. H. (1991) Focus on form: A design feature in language teaching methodology. In Bot, K. D., Ginsberg, R. and Kramsch, C. (eds.), Foreign Language Research in Cross-Cultural Perspective. Amsterdam: John Benjamins, 39-52.

Long, M. H. and Crookes, G. (1992) Three approaches to task based syllabus design. TESOL Quarterly, 26(1): 27-56.

Long, M. H. and Crookes, G. (1993) The authors respond. TESOL Quarterly, 27(4): 729-733.

Long, M. H. and Robinson, P. (1998) Focus on form: theory, research and practice. In: Doughty, C. and Williams, J. (eds.), Focus on form in classroom second language acquisition. Cambridge: Cambridge University Press, 15-41.

Negretti, R. (1999) Web-based activities and SLA: A conversation analysis research approach. Language Learning \& Technology, 3(1): 75-87.

McAndrew, P., Foubister, S. P., and Mayes, T. (1996) Videoconferencing in a language learning 
application. Interacting with Computers, 8(2): 207-217.

O'Dowd, R. (2000) Intercultural learning via videoconferencing: a pilot exchange project. ReCALL, 12(1): 49-62.

Pellettieri, J. (2000) Negotiation in cyberspace: The role of chatting in the development of grammatical competence. In: Warschauer, M. and Kern, R. (eds.), Network-based language teaching: Concepts and practice. Cambridge: Cambridge University Press, 59-86.

Pica, T. (1994) Research on negotiation: what does it reveal about second language learning conditions, processes, and outcomes? Language Learning, 44(3), 491-527.

Pica, T., Kanagy, R. and Falodun, J. (1993) Choosing and using communication tasks for second language instruction. In: Cookes, G. and Gass, S. M. (eds.), Tasks and language learning: Integrating theory \& practice. Clevedon, England: Multilingual Matters, 9-34.

Shield, L., Hauck, M. and Hewer, S. (2001) Talking to strangers - the role of the tutor in developing target language speaking skills at a distance. Proceedings of UNTELE 2000, II.

Skehan, P. (1998) A cognitive approach to language learning. Oxford: Oxford University Press.

Smith, M. and Salam, U. (2000) Web-based ESL courses: A search for industry standards. http://www.clec.ritsumei.ad.jp/english/callejonline//5-1/msith\&salam.html. [2001, 9 September].

Smith, B. (2003) Computer mediated negotiated interaction: An expanded model. The Modern Language Journal, 87(1): 38-57.

Sotillo, S. M. (2000) Discourse functions and syntactic complexity in synchronous and asynchronous communication. Language Learning and Technology, 4(1): 82-119.

Stevens, V. and Altun, A. (2002) The Webheads community of language learners online. In: Syed, Z. (ed.) The process of language learning: An EFL perspective. Abu Dhabi: The Military Language Institute, 285-318.

Tudini, V. (2003) Using native speakers in chat. Language Learning and Technology, 7(3):141-159.

Tudini, V. (2005) Chatlines for beginners: Negotiating conversation at a distance. In: Holmberg, B., Shelley, M. and White, C. (eds.) Distance Education and Languages: Evolution and Change. Clevedon: Multilingual Matters Ltd, 212-229.

Varonis, E. M. and Gass, S. M. (1985) Non-native/non-native conversation: A model for negotiation of meaning. Applied Linguistics, 6(1): 71-90.

Wang, Y. (2004a) Distance language learning: Interactivity and fourth-generation Internet-based videoconferencing. CALICO Journal, 21(2): 373-395.

Wang, Y. (2004b) Internet-based desktop videoconferencing in supporting synchronous distance language learning. Language Learning and Technology, 8 (3): 90-121.

Wong, J. and Fauverge, A. (1999) LEVERAGE - Reciprocal peer tutoring over broadband networks. ReCALL, 11(1): 133-142. 
Appendix I

Three sets of videoconferencing tasks are shown in Tables A.1-A.3.

Table A.1 Set 1

\begin{tabular}{|c|c|c|c|}
\hline $\begin{array}{l}\text { Sub- } \\
\text { tasks }\end{array}$ & Task description & Aim & $\begin{array}{l}\text { NetMeeting } \\
\text { feature used }\end{array}$ \\
\hline & $\begin{array}{l}\text { You are to play the role of an applicant. You saw an advertisement in the Courier } \\
\text { Mail about a part time job at LELE in Chinatown. You want to know more about } \\
\text { the job, so you ring the shop and ask to speak to the manager. You need to first } \\
\text { introduce yourself and then find out: } \\
\text { - what kind of person they are looking for; } \\
\text { - how many hours the applicant would be required to work every week; } \\
\text { • what the hourly rate is; } \\
\text { (e.g. in the morning, afternoon or weekend) } \\
\text { - when the job starts. } \\
\text { The manager will ask questions about the applicant such as age, language } \\
\text { abilities, likes and dislikes. }\end{array}$ & $\begin{array}{l}\text { 1. To practise } \\
\text { making a phone } \\
\text { call } \\
2 \text { To } \\
\text { practise } \\
\text { introducing } \\
\text { oneself }\end{array}$ & $\begin{array}{c}\text { Video- } \\
\text { conferencing } \\
\text { and } \\
\text { Whiteboard }\end{array}$ \\
\hline & $\begin{array}{l}\text { Being very nervous about the application, you decide to ring your friend, Linda, } \\
\text { who used to work at LELE as a shop assistant. You arrange to meet at a Café in } \\
\text { the city the next day. You will need to } \\
\text { - tell Linda what happened the previous day about the job inquiry; } \\
\qquad \text { ask Linda what it was like working at LELE; } \\
\text { - arrange to meet Linda at a cafe in the city (You will suggest a newly opened } \\
\text { Cafe in the City Mall and heap praise on it); } \\
\text { - draw a map on the Whiteboard to show Linda the location of the cafe }\end{array}$ & $\begin{array}{l}\text { 1. To practise } \\
\text { making a phone call } \\
\text { 2. To practise } \\
\text { making an } \\
\text { appointment. (time, } \\
\text { place, etc). } \\
\text { 3. To practise } \\
\text { giving directions }\end{array}$ & $\begin{array}{l}\text { Video- } \\
\text { conferencing } \\
\text { and the } \\
\text { Whiteboard }\end{array}$ \\
\hline & $\begin{array}{l}\text { You and Linda meet at the cafe. You will need to discuss with Linda what drinks } \\
\text { and food to order; } \\
\text { - comment on the price; } \\
\text { • place an order; } \\
\text { • ask Linda's opinion about working at LELE; } \\
\text { • tell Linda why you are nervous about working at LELE; } \\
\text { tell Linda that you will ring her and tell her your decision; } \\
\text { - Linda shows a photo of the people who used to work with her at LELE and } \\
\text { introduces the people in the photo. }\end{array}$ & $\begin{array}{l}\text { 1. Practise } \\
\text { ordering food and } \\
\text { drinks } \\
\text { 2. Practise talking } \\
\text { about price. } \\
\text { 3. Practise } \\
\text { describing people. }\end{array}$ & $\begin{array}{l}\text { Video- } \\
\text { conferencing } \\
\text { and the } \\
\text { "Sharing" } \\
\text { function }\end{array}$ \\
\hline & $\begin{array}{l}\text { After much deliberation about the job, you decide to ring LELE and ask for an } \\
\text { interview. The first time you ring, you only hear a message on an answering } \\
\text { machine asking you to leave a message. The manager returns the call later and } \\
\text { you arrange to meet at Griffith University the next day. You will need to } \\
\text { • remind the manager of who you are; } \\
\qquad \text { ask for an interview; } \\
\qquad \text { make sure where and how to find LELE; } \\
\text { • confirm time and place for the interview. }\end{array}$ & $\begin{array}{l}\text { 1. Practise again } \\
\text { making a telephone } \\
\text { conversation, } \\
\text { 2. Practise making } \\
\text { an appointment. } \\
\text { 3. Practise talking } \\
\text { about directions }\end{array}$ & $\begin{array}{l}\text { Video- } \\
\text { conferencing, } \\
\text { Whiteboard } \\
\text { "Sharing" and } \\
\text { file transfer }\end{array}$ \\
\hline & $\begin{array}{l}\text { You and the manager meet at Griffith University bus stop. You first show the } \\
\text { manager around Griffith University. Later at the interview, you give a copy of } \\
\text { your resume to the manager and try hard to sell yourself. You will need to } \\
\text { - prepare a "resume" (You can save an existing resume onto a floppy disk and } \\
\text { bring the disk to this session. Or you can type a new one in Chinese ); } \\
\text { • talk about why you want to apply for this job; } \\
\text { tell the manager your qualifications (what you have learned, what you are } \\
\text { learning and your language abilities etc.); } \\
\text { - elaborate on your previous work experience; } \\
\text { - ask if you get the job, what you are expected to do; } \\
\text { - inquire about your pay, how many hours you are expected to work and if you } \\
\text { need to work during weekends or evenings and what is the rate for working in } \\
\text { evenings and weekends; } \\
\text { accept or refuse the job offer. }\end{array}$ & 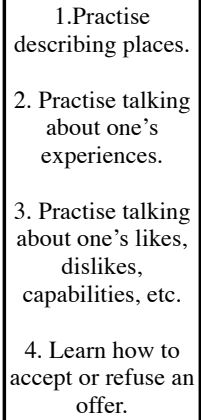 & $\begin{array}{l}\text { Video- } \\
\text { conferencing, } \\
\text { "sharing" and } \\
\text { file transfer }\end{array}$ \\
\hline
\end{tabular}


Table A.2 Set 2

\begin{tabular}{|c|c|c|c|}
\hline $\begin{array}{l}\text { Sub- } \\
\text { tasks }\end{array}$ & Task description & Aim & $\begin{array}{l}\text { NetMeeting } \\
\text { feature used }\end{array}$ \\
\hline & $\begin{array}{l}\text { 1. Free conversation (5-10 minutes) } \\
\text { 2. You are to play the role of an applicant. You saw an advertisement in the } \\
\text { Courier Mail about a part time job at LELE in Chinatown. You want to know } \\
\text { more about the job, so you ring the shop and ask to speak to the manager. You } \\
\text { will need to first introduce yourself and then find out: } \\
\text { • what kind of person they are looking for; } \\
\text { - how many hours the applicant would be required to work every week; } \\
\text { what the hourly rate is; } \\
\text { - when the applicant would be required to work, (e.g. in the morning, afternoon } \\
\text { or weekend) } \\
\text { - when the job starts. } \\
\text { 3. The manager will ask questions about the applicant such as age, language } \\
\text { abilities, likes and dislikes. }\end{array}$ & $\begin{array}{c}\text { 1. To practise } \\
\text { making a phone } \\
\text { call } \\
2 \text { To } \\
\text { practise } \\
\text { introducing oneself }\end{array}$ & $\begin{array}{c}\text { Video- } \\
\text { conferencing } \\
\text { and } \\
\text { Whiteboard }\end{array}$ \\
\hline & $\begin{array}{l}\text { 1. Free conversation (5-10 minutes) } \\
\text { 2. Being very nervous about the application, you decide to ring your friend, } \\
\text { Linda, who used to work at LELE as a shop assistant. You arrange to meet at a } \\
\text { Café in the city the next day. You will need to } \\
\text { - tell Linda what happened the previous day about the job inquiry; } \\
\text { • ask Linda what it was like working at LELE; } \\
\text { - arrange to meet Linda at a cafe in the city (You will suggest a newly opened } \\
\text { Cafe in the City Mall and heap praise on it); } \\
\text { - draw a map on the Whiteboard to show Linda the location of the cafe }\end{array}$ & $\begin{array}{l}\text { 1. To practise } \\
\text { making a phone call } \\
\text { 2. To practise } \\
\text { making an } \\
\text { appointment. } \\
\text { (time, place, etc). } \\
\text { 3. To practise } \\
\text { giving directions }\end{array}$ & $\begin{array}{l}\text { Video- } \\
\text { conferencing } \\
\text { and the } \\
\text { Whiteboard }\end{array}$ \\
\hline & $\begin{array}{l}\text { 1. Free conversation (5-10 minutes) } \\
\text { 2. You and Linda meet at the cafe. You will need to } \\
\text { - discuss with Linda what drinks and food to order; } \\
\text { - comment on the price; } \\
\text { • place an order; } \\
\text { • ask Linda's opinion about working at LELE; } \\
\text { • tell Linda why you are nervous about working at LELE; } \\
\text { - tell Linda that you will ring her and tell her your decision; } \\
\text { - Linda shows a photo of the people who used to work with her at LELE and } \\
\text { introduces the people in the photo. }\end{array}$ & $\begin{array}{l}\text { 1. Practise } \\
\text { ordering food and } \\
\text { drinks } \\
\text { 2. Practise talking } \\
\text { about price. } \\
\text { 3. Practise } \\
\text { describing people. }\end{array}$ & $\begin{array}{l}\text { Video- } \\
\text { conferencing } \\
\text { and the } \\
\text { "Sharing" } \\
\text { function }\end{array}$ \\
\hline & $\begin{array}{l}\text { 1. Free conversation (5-10 minutes) } \\
\text { 2. After much deliberation about the job, you decide to ring LELE and ask for an } \\
\text { interview. The first time you ring, you only hear a message on an answering } \\
\text { machine asking you to leave a message. The manager returns the call later and } \\
\text { you arrange to meet at Griffith University the next day. You will need to } \\
\text { - remind the manager of who you are; } \\
\qquad \text { ask for an interview; } \\
\text { - make sure where and how to find LELE; } \\
\text { - confirm time and place for the interview. }\end{array}$ & $\begin{array}{l}\text { 1. Practise again } \\
\text { making a telephone } \\
\text { conversation, } \\
\text { 2. Practise making } \\
\text { an appointment. } \\
\text { 3. Practise talking } \\
\text { about directions }\end{array}$ & $\begin{array}{l}\text { Video- } \\
\text { conferencing, } \\
\text { Whiteboard } \\
\text { "Sharing" and } \\
\text { file transfer }\end{array}$ \\
\hline & $\begin{array}{l}\text { 1. Free conversation (5-10 minutes) } \\
\text { 2. You and the manager meet at Griffith University bus stop. You first show the } \\
\text { manager around Griffith University. Later at the interview, you give a copy of } \\
\text { your resume to the manager and try hard to sell yourself. You will need to } \\
\text { - prepare a "resume" (You can save an existing resume onto a floppy disk and } \\
\text { bring the disk to this session. Or you can type a new one in Chinese); } \\
\text { • talk about why you want to apply for this job; } \\
\text { tell the manager your qualifications (what you have learned, what you are } \\
\text { learning and your language abilities etc.); } \\
\text { • elaborate on your previous work experience; } \\
\text { • ask if you get the job, what you are expected to do; } \\
\text { - inquire about your pay, how many hours you are expected to work and if you } \\
\text { need to work during weekends or evenings and what is the rate for working in } \\
\text { evenings and weekends; } \\
\text {-accept or refuse the job offer. }\end{array}$ & $\begin{array}{l}\text { 1.Practise } \\
\text { describing places. } \\
\text { 2. Practise talking } \\
\text { about one's } \\
\text { experiences. } \\
\text { 3. Practise talking } \\
\text { about one's likes, } \\
\text { dislikes, } \\
\text { capabilities, etc. } \\
\text { 4. Learn how to } \\
\text { accept or refuse an } \\
\text { offer. }\end{array}$ & $\begin{array}{l}\text { Videoconfer } \\
\text { encing, } \\
\text { "sharing" } \\
\text { and file } \\
\text { transfer }\end{array}$ \\
\hline
\end{tabular}


Table A.3 Set 3

\begin{tabular}{|c|c|c|c|}
\hline $\begin{array}{l}\text { Sub- } \\
\text { tasks }\end{array}$ & Task description & Aims & $\begin{array}{l}\text { NetMeeting } \\
\text { feature used }\end{array}$ \\
\hline & $\begin{array}{l}\text { Talking about myself. } \\
\text { A: You can tell your teacher anything about yourself, e.g. } \\
\text { 1. a brief self- introduction, } \\
\text { 2. your work, } \\
\text { 3. your study, } \\
\text { 4. what you do everyday, } \\
\text { 5. where you live etc. } \\
\text { B: Be prepared to ask about your teacher. }\end{array}$ & $\begin{array}{c}\text { Linguistic: } \\
\text { Practise using the present continuous } \\
\text { tense (zai). } \\
\text { Functional: } \\
\text { Self introduction } \\
\text { How to ask a } \\
\text { question politely (qingwen). } \\
\text { Interactional: } \\
\text { How to check understanding in } \\
\text { Chinese }\end{array}$ & $\begin{array}{c}\text { The } \\
\text { Whiteboard }\end{array}$ \\
\hline & $\begin{array}{l}\text { Talking about family members } \\
\text { A: You can use a photo as a prompter to describe each } \\
\text { family member: } \\
\text { 1. their name, } \\
\text { 2. age, } \\
\text { 3. birthday, } \\
\text { 4. likes and dislikes. } \\
\text { B: You also need to prepare to ask your teacher about her } \\
\text { family members }\end{array}$ & $\begin{array}{c}\text { Linguistic: } \\
\text { Practise how to use you (there is/are) } \\
\text { Functional: } \\
\text { 1.Practise the different ways of } \\
\text { asking about one's age. } \\
\text { 2. Practise how to say age and dates. } \\
\text { 3. Practise talking about one's habits. } \\
\text { Interactional: } \\
\text { 1. Practise how to clarify meaning } \\
\text { using Chinese. } \\
\text { 2. Practise how to check } \\
\text { understanding using Chinese }\end{array}$ & $\begin{array}{c}\text { The } \\
\text { Whiteboard }\end{array}$ \\
\hline & $\begin{array}{l}\text { What I did yesterday } \\
\text { A: Prepare to tell the teacher about the major events that } \\
\text { happened yesterday such as where you went, what you did } \\
\text { and why you did it etc. } \\
\text { B:You will also need to ask your teacher about the things } \\
\text { she did yesterday. }\end{array}$ & $\begin{array}{l}\text { Linguistic: } \\
\text { 1. Practise the use of le to } \\
\text { indicate completion of an action. } \\
\text { 2. Practise the use of you } \\
\text { (again). } \\
\text { Functional: } \\
\text { Practise asking questions } \\
\text { regarding what happened. } \\
\text { Interactional: } \\
\text { 1. Practise how to clarifymeaning } \\
\text { using Chinese } \\
\text { 2. Practise how to negotiate } \\
\text { meaning using Chinese }\end{array}$ & $\begin{array}{c}\text { The } \\
\text { Whiteboard }\end{array}$ \\
\hline & $\begin{array}{l}\text { Going out together Part two: } \\
\text { You and Linda are at the coffee shop. You can start the } \\
\text { conversation by apologizing for being late, and then ask } \\
\text { Linda how and when she came. You will then discuss with } \\
\text { Linda what to order and comment on the prices and the food } \\
\text { and drinks. You can end the meeting by saying that you have } \\
\text { to go because you have to meet someone at Hoyts cinema. }\end{array}$ & $\begin{array}{l}\text { Linguistic: } \\
\text { 1. Practise the structure of shi ...de } \\
\text { Functional: } \\
\text { 1. practise apologizing. } \\
\text { 2. practise ordering food and drinks } \\
\text { 3. practise talking about money } \\
\text { 4. practise taking leave of someone. } \\
\text { Interactional: } \\
\text { 1. Practise how to clarify meaning } \\
\text { using Chinese } \\
\text { 2. Practise how to negotiate meaning } \\
\text { using Chinese } \\
\text { Practise how to check } \\
\text { 3. } \text { understanding in Chinese. }\end{array}$ & $\begin{array}{c}\text { The } \\
\text { Whiteboard } \\
\text { and File } \\
\text { Transfer }\end{array}$ \\
\hline
\end{tabular}

